\title{
Molecular design of metal-free $D-\pi$-A substituted sensitizers for dye-sensitized solar cells
}

\author{
L. Alibabaei, $\dagger^{a}$ J.-H. Kim, ${ }^{b c}$ M. Wang, $\dagger^{a}$ N. Pootrakulchote, ${ }^{a}$ J. Teuscher, ${ }^{a}$ D. Di Censo, ${ }^{a}$ R. Humphry-Baker, ${ }^{a}$

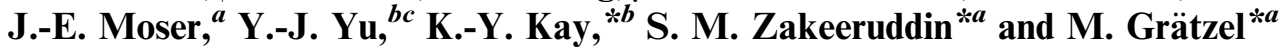

Received 4th July 2010, Accepted 11th August 2010

DOI: $10.1039 / \mathrm{c0ee00218f}$

\begin{abstract}
Novel donor- $\pi$-acceptor (D- $\pi$-A) dyes, coded as SD-1, SD-2 and SD-5, were designed and synthesized for dye-sensitized solar cells. All these dyes comprised the same donor and acceptor units while the oligo thiophene units were introduced as linkers between the donor and acceptor units. The photophysical and electrochemical properties of the dyes were investigated by UV/vis spectrometry and cyclic voltammetry. The dyes were subsequently tested as sensitizers in dye-sensitized solar cells. Photovoltaic performance of the device with SD-2 dye showed maximum monochromatic incident photon-to-current efficiency (IPCE) of $82 \%$ and an over all conversion efficiency of $6.2 \%$ under full sunlight (AM 1.5G, $100 \mathrm{~mW} \mathrm{~cm}^{-2}$ ) irradiation.
\end{abstract}

\section{Introduction}

Dye-sensitized solar cells (DSCs) have attracted significant attention as low-cost alternatives to conventional semiconductor photovoltaic devices. ${ }^{\mathbf{1} 2}$ These cells are composed of a wide band gap $\mathrm{TiO}_{2}$ semiconductor deposited on a transparent conducting substrate, an anchored molecular sensitizer, and a redox electrolyte. Ruthenium sensitizers have shown very impressive solar-toelectric power conversion efficiencies, reaching $11 \%$ under standard AM 1.5G sunlight. ${ }^{3-6}$ Several groups, including ours, have developed metal-free organic sensitizers and thus highly efficient DSC devices were obtained. ${ }^{7-18}$ Critical factors that influence sensitization are the excited-state redox potential, which should

${ }^{a}$ Laboratory for Photonics and Interfaces, Swiss Federal Institute of Technology, CH 1015 Lausanne, Switzerland. E-mail: shaik.zakeer@, epfl.ch; michael.graetzel@epfl.ch

${ }^{b}$ Department of Molecular Science and Technology, Ajou University, Suwon,443-749, Korea.E-mail: kykay@ajou.ac.kr

'SolarSys Co., Ltd., BI Center, Ajou University, Suwon, 443-749, Korea $\dagger$ Present address: Chemistry section of School of Environmental Sciences, University of Camerino, Via S. Agostino 1, 62032 Camerino, Italy.

† Present address: Wuhan National Laboratory for Optoelectronics, Huazhong University of Science and Technology, 1037 Luoyu Road, Wuhan, 430074, PR China. match the energy of the conduction band edge of the oxide, light excitation associated with vectorial electron flow from the lightharvesting moiety of the dye toward the surface of the semiconductor surface, conjugation across the donor and anchoring groups, and electronic coupling between the lowest unoccupied molecular orbital (LUMO) of the dye and the $\mathrm{TiO}_{2}$ conduction band. The major factors for low conversion efficiency of many organic dyes in the DSC are the formation of dye aggregates on the semiconductor surface and recombination of conductionband electrons with triiodide present in the electrolyte. ${ }^{19}$

Therefore, to obtain optimal performance, aggregation of organic dyes and recombination need to be avoided through appropriate structural modification..$^{20,21}$ On the basis of this strategy, we have designed and synthesized a series of organic dyes SD-1, SD-2, and SD-5 substituted with coumarin on the donor side (Fig. 1). Here, we report photovoltaic performance of the SD-1, SD-2 and SD-5 sensitizers using liquid electrolyte or spiro-MeOTAD as hole transporting material.

\section{Experimental section}

\section{Materials and instruments}

4-[N,N-Bis(4-iodophenyl)amino] benzaldehyde (1), ${ }^{22}$ 7-diethylamino-3-vinyl-coumarin (2) ${ }^{23}$ and tris(4-iodophenyl)amine (4) ${ }^{24}$

\section{Broader context}

Dye-sensitized solar cells (DSCs) have achieved an impressive solar energy conversion efficiency of over $11 \%$ with ruthenium complexes as a sensitizer. Compared to ruthenium complexes, the advantage of organic dyes lies in their high molar extinction coefficients and flexibility in molecular tailoring at lower cost. In order to achieve high photovoltaic performance values utilizing organic dye sensitizers, fundamental investigations need to be made. Here, we present novel organic sensitizers (triphenylamine based dyes) comprised the same donor and acceptor units while the oligo thiophene units were introduced as linkers between the donor and acceptor units. Increasing the number of thiophene units in the spacer shifts the spectral response to the red region of absorption spectra and enhances the photovoltaic performance of the devices by increasing the $J_{\text {sc }}$ values with the absorption of more red photons. Laser studies indicate that there is a loss in efficiency of the interception of geminate recombination by iodide present in the redox electrolyte upon addition of thiophene units. 
were synthesized according to the corresponding literature methods. Reagents and solvents were purchased as reagent grade and used without further purification. All reactions were performed using dry glassware under nitrogen atmosphere. Analytical TLC was carried out on Merck 60 F254 silica gel plate and column chromatography was performed on Merck 60 silica gel (230-400 mesh). Melting points were determined on an Electrothemal IA 9000 series melting point apparatus and are uncorrected. NMR spectra were recorded on a Varian Mercury$400(400 \mathrm{MHz})$ spectrometer with TMS peak as reference. UV/vis spectra were recorded on a Jasco V-550 spectrometer. MALDITOF MS spectra were recorded with an Applied Biosystems Voyager-DE-STR. Elemental analyses were performed with a Perkin-Elmer 2400 analyzer.

\section{4-[N,N-Bis\{4-(7-diethylaminocoumarin-3-yl)-ethen-3-y]- phenyl \}amino|benzaldehyde (3)}

To a solution of compound $\mathbf{1}(0.15 \mathrm{~g}, 0.28 \mathrm{mmol})$ and compound $2(0.15 \mathrm{~g}, 0.68 \mathrm{mmol})$ in DMF $(10 \mathrm{~mL})$ were added $\mathrm{Pd}(\mathrm{OAc})_{2}$ ( $3 \mathrm{mg}, 0.014 \mathrm{mmol}), \mathrm{Bu}_{4} \mathrm{NBr}(0.18 \mathrm{~g}, 0.57 \mathrm{mmol})$ and $\mathrm{K}_{2} \mathrm{CO}_{3}$ $(0.14 \mathrm{~g}, 1.16 \mathrm{mmol})$, and the mixture was stirred at $95^{\circ} \mathrm{C}$ for $6 \mathrm{~h}$. After cooling, the solution was poured into water $(50 \mathrm{~mL})$ and the crude product was extracted with dichloromethane $(3 \times 50$ $\mathrm{mL}$ ). The organic layer was dried over $\mathrm{Na}_{2} \mathrm{SO}_{4}$ and the solvent was removed under reduced pressure. The residue was chromatographed on silica gel with ethylacetate/ $n$-hexane $(1: 1)$ to give compound $3(0.12 \mathrm{~g}, 60.0 \%)$ in a yellowish solid, $\mathrm{mp} 183-185^{\circ} \mathrm{C}$. ${ }^{1} \mathrm{H}$ NMR $\left(400 \mathrm{MHz}, \mathrm{CDCl}_{3}\right): \delta=9.81(\mathrm{~s}, 1 \mathrm{H}), 7.70(\mathrm{~d}, J=8.8$ $\mathrm{Hz}, 2 \mathrm{H}), 7.65(\mathrm{~s}, 2 \mathrm{H}), 7.45(\mathrm{~m}, 6 \mathrm{H}), 7.26(\mathrm{~d}, J=8.8 \mathrm{~Hz}, 2 \mathrm{H}), 7.11$ $(\mathrm{d}, J=8.8 \mathrm{~Hz}, 4 \mathrm{H}), 7.04(\mathrm{~m}, 4 \mathrm{H}), 6.58(\mathrm{dd}, J=2.4,2.4 \mathrm{~Hz}, 2 \mathrm{H})$, $6.49(\mathrm{~d}, J=2.4 \mathrm{~Hz}, 2 \mathrm{H}), 3.42(\mathrm{q}, 8 \mathrm{H}), 1.22(\mathrm{t}, 12 \mathrm{H})$. Anal. calcd (\%) for $\mathrm{C}_{49} \mathrm{H}_{45} \mathrm{~N}_{3} \mathrm{O}_{5}$ : C 77.86, $\mathrm{H} 6.00, \mathrm{~N}$ 5.56. Found: C 77.64, $\mathrm{H}$ 6.05 , N 5.53\%.

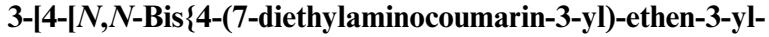 phenyl\}amino|phenyll-2-cyanoacrylic acid (SD-1)}

To a solution of compound $3(0.30 \mathrm{~g}, 0.34 \mathrm{mmol})$ in chloroform $(30 \mathrm{~mL})$ were added cyanoacetic acid $(0.29 \mathrm{~g}, 3.37 \mathrm{mmol})$ and piperidine $(0.1 \mathrm{~mL}, 1.01 \mathrm{mmol})$, and the mixture was refluxed for $6 \mathrm{~h}$. After cooling, the solution was poured into water $(50 \mathrm{~mL})$ and the crude product was extracted with chloroform $(3 \times 50$ $\mathrm{mL}$ ). The organic layer was dried over $\mathrm{Na}_{2} \mathrm{SO}_{4}$ and the solvent was removed under reduced pressure. The residue was chromatographed on silica gel with methanol/dichloromethane $(1: 6)$ to give compound SD-1 $(0.24 \mathrm{~g}, 74.4 \%)$ in a red solid, $\mathrm{mp} 212-213$ ${ }^{\circ} \mathrm{C} .{ }^{1} \mathrm{H}$ NMR (400 MHz, DMSO- $d_{6}$ ): $\delta=8.04$ (s, 2H), 7.83 (s, $1 \mathrm{H}), 7.80(\mathrm{~d}, J=8.8 \mathrm{~Hz}, 2 \mathrm{H}), 7.52(\mathrm{~d}, J=8.8 \mathrm{~Hz}, 4 \mathrm{H}), 7.46(\mathrm{~d}$, $J=8.8 \mathrm{~Hz}, 2 \mathrm{H}), 7.43(\mathrm{~s}, 2 \mathrm{H}), 7.08(\mathrm{~d}, J=8.8 \mathrm{~Hz}, 4 \mathrm{H}), 7.03(\mathrm{~m}$, $4 \mathrm{H}), 6.70(\mathrm{dd}, J=2.4,2.4 \mathrm{~Hz}, 2 \mathrm{H}), 6.54(\mathrm{~d}, J=2.4 \mathrm{~Hz}, 2 \mathrm{H}), 3.47$ (q, $8 \mathrm{H}), 1.25(\mathrm{t}, 12 \mathrm{H})$. MS (MALDI-TOF): $\mathrm{m} / \mathrm{z} 823.2\left[\mathrm{M}^{+}\right]$(calcd for $\mathrm{C}_{52} \mathrm{H}_{46} \mathrm{~N}_{4} \mathrm{O}_{6}$ 822.9). Anal. calcd (\%) for $\mathrm{C}_{52} \mathrm{H}_{46} \mathrm{~N}_{4} \mathrm{O}_{6}$ : C 75.89, H 5.63, N 6.81. Found: C 75.67, H 5.78, N 6.65\%.

\section{2-[4- $\{N, N$-Bis(4-iodophenyl) $\}$ aminolphenyl-thiophene (5)}

To a solution of compound 4 (4.86 g, $7.82 \mathrm{mmol})$ and 2-thienylboronic acid $(1.0 \mathrm{~g}, 7.82 \mathrm{mmol})$ in DMF $(10 \mathrm{~mL})$ were added $\mathrm{Pd}(\mathrm{OAc})_{2}(88 \mathrm{mg}, 0.40 \mathrm{mmol}), \mathrm{PPh}_{3}(0.42 \mathrm{~g}, 1.60 \mathrm{mmol})$ and
$\mathrm{K}_{2} \mathrm{CO}_{3}(2.86 \mathrm{~g}, 23.76 \mathrm{mmol})$, and the mixture was stirred at $80^{\circ} \mathrm{C}$ for $2 \mathrm{~h}$. After cooling, the solution was poured into water $(50 \mathrm{~mL})$ and the crude product was extracted with dichloromethane $(3 \times$ $50 \mathrm{~mL}$ ). The organic layer was dried over $\mathrm{Na}_{2} \mathrm{SO}_{4}$ and the solvent was removed under reduced pressure. The residue was chromatographed on silica gel with dichloromethane $/ n$-hexane $(1: 3)$ to give compound $5(1.20 \mathrm{~g}, 26.5 \%)$ in a white solid, $\mathrm{mp} 127-129^{\circ} \mathrm{C}$. ${ }^{1} \mathrm{H}$ NMR (400 MHz, $\mathrm{CDCl}_{3}$ ): $\delta=7.52(\mathrm{~d}, J=8.8 \mathrm{~Hz}, 4 \mathrm{H}), 7.47$ $(\mathrm{d}, J=8.8 \mathrm{~Hz}, 2 \mathrm{H}), 7.22(\mathrm{~m}, 1 \mathrm{H}), 7.06-7.01(\mathrm{~m}, 3 \mathrm{H}), 6.84(\mathrm{~d}, J=$ $8.8 \mathrm{~Hz}, 4 \mathrm{H}), 7.79(\mathrm{~d}, J=8.8 \mathrm{~Hz}, 1 \mathrm{H})$. Anal. calcd (\%) for $\mathrm{C}_{22} \mathrm{H}_{15} \mathrm{NSI}_{2}$ : C 45.62, H 2.61, N 2.42, S 5.54. Found: C 45.33, H $2.94, \mathrm{~N} 2.33$, S $5.40 \%$.

\section{5-[4-\{N,N-Bis(4-iodophenyl)\}amino|phenyl-thiophene-2- carboxaldehyde (6)}

To a solution of compound $5(1.84 \mathrm{~g}, 1.45 \mathrm{mmol})$ in 1,2-dichloroethane $(30 \mathrm{~mL})$ were added DMF $(0.34 \mathrm{~mL}, 4.35 \mathrm{mmol})$ and $\mathrm{POCl}_{3}(0.41 \mathrm{~mL}, 4.35 \mathrm{mmol})$, and the mixture was refluxed for $16 \mathrm{~h}$. After cooling, the solution was poured into saturated aqueous sodium acetate solution $(50 \mathrm{~mL})$ and the crude product was extracted with dichloromethane $(3 \times 50 \mathrm{~mL})$. The organic layer was dried over $\mathrm{Na}_{2} \mathrm{SO}_{4}$ and the solvent was removed under reduced pressure. The residue was chromatographed on silica gel with dichloromethane/ $n$-hexane $(1: 1)$ to give compound $\mathbf{6}$ $(0.60 \mathrm{~g}, 68.2 \%)$ in a yellowish solid, mp $158{ }^{\circ} \mathrm{C} .{ }^{1} \mathrm{H}$ NMR (400 $\left.\mathrm{MHz}, \mathrm{CDCl}_{3}\right): \delta=9.85(\mathrm{~s}, 1 \mathrm{H}), 7.70(\mathrm{~d}, J=4.0 \mathrm{~Hz}, 1 \mathrm{H}), 7.56(\mathrm{~d}$, $J=8.8 \mathrm{~Hz}, 4 \mathrm{H}), 7.52(\mathrm{~d}, J=8.8 \mathrm{~Hz}, 2 \mathrm{H}), 7.30(\mathrm{~d}, J=4.0 \mathrm{~Hz}$, $1 \mathrm{H}), 7.05(\mathrm{~d}, J=8.8 \mathrm{~Hz}, 2 \mathrm{H}), 6.70(\mathrm{~d}, J=8.8 \mathrm{~Hz}, 4 \mathrm{H})$. Anal. calcd (\%) for $\mathrm{C}_{23} \mathrm{H}_{15} \mathrm{NOSI}_{2}$ : C 45.49, H 2.49, N 2.31, S 5.28. Found: C 45.20, H 2.61, N 2.13, S 5.07\%.

\section{5-[4-[N, $N$-Bis \{4-(7-diethylaminocoumarin-3-y])-ethen-3-y]- phenyl\}amino||phenyl-2-thiophene carboxaldehyde (7)}

To a solution of compound $6(0.28 \mathrm{~g}, 0.46 \mathrm{mmol})$ and compound $2(0.41 \mathrm{~g}, 1.68 \mathrm{mmol})$ in DMF $(20 \mathrm{~mL})$ were added $\mathrm{Pd}(\mathrm{OAc})_{2}$ (5 mg, $0.023 \mathrm{mmol}), \mathrm{Bu}_{4} \mathrm{NBr}(0.30 \mathrm{~g}, 0.92 \mathrm{mmol})$ and $\mathrm{K}_{2} \mathrm{CO}_{3}$ $(0.23 \mathrm{~g}, 1.84 \mathrm{mmol})$, and the mixture was stirred at $95^{\circ} \mathrm{C}$ for $16 \mathrm{~h}$. After cooling, the solution was poured into water $(50 \mathrm{~mL})$ and the crude product was extracted with dichloromethane $(3 \times$ $50 \mathrm{~mL}$ ). The organic layer was dried over $\mathrm{Na}_{2} \mathrm{SO}_{4}$ and the solvent was removed under reduced pressure. The residue was chromatographed on silica gel with dichloromethane to give compound $7(0.36 \mathrm{~g}, 100 \%)$ in a red solid, mp $211^{\circ} \mathrm{C} .{ }^{1} \mathrm{H}$ NMR $(400 \mathrm{MHz}$, $\left.\mathrm{CDCl}_{3}\right): \delta=9.81(\mathrm{~s}, 1 \mathrm{H}), 7.70(\mathrm{~d}, J=4.0 \mathrm{~Hz}, 1 \mathrm{H}), 7.65(\mathrm{~s}, 2 \mathrm{H})$, $7.53(\mathrm{~d}, J=8.8 \mathrm{~Hz}, 2 \mathrm{H}), 7.43(\mathrm{~d}, J=8.8 \mathrm{~Hz}, 4 \mathrm{H}), 7.40(\mathrm{~s}, 2 \mathrm{H})$, $7.31(\mathrm{~d}, J=4.0 \mathrm{~Hz}, 1 \mathrm{H}), 7.28(\mathrm{~d}, J=8.8 \mathrm{~Hz}, 4 \mathrm{H}), 7.13(\mathrm{~d}, J=8.8$ $\mathrm{Hz}, 2 \mathrm{H}), 7.09$ (d, $J=8.8 \mathrm{~Hz}, 4 \mathrm{H}), 6.58(\mathrm{dd}, J=2.4,2.4 \mathrm{~Hz}, 2 \mathrm{H})$, $6.50(\mathrm{~d}, J=2.4 \mathrm{~Hz}, 2 \mathrm{H}), 3.42(\mathrm{q}, 8 \mathrm{H}), 1.22(\mathrm{t}, 12 \mathrm{H})$. Anal. calcd (\%) for $\mathrm{C}_{53} \mathrm{H}_{47} \mathrm{~N}_{3} \mathrm{O}_{5} \mathrm{~S}$ : C 75.96, H 5.65, N 5.01, S 3.83. Found: C 75.77, H 5.83, N 4.89, S 3.67\%.

\section{3-[5-[4-[N, N-Bis $\{4-(7-d i e t h y l a m i n o c o u m a r i n-3-y])-e t h e n-3-y]-$ phenyl amino||phenyl-thien-2-yl]-2-cyanoacrylic acid (SD-2)}

To a solution of compound $7(0.36 \mathrm{~g}, 0.43 \mathrm{mmol})$ in chloroform $(30 \mathrm{~mL})$ were added cyanoacetic acid $(0.37 \mathrm{~g}, 4.30 \mathrm{mmol})$ and piperidine $(0.13 \mathrm{~mL}, 1.29 \mathrm{mmol})$, and the mixture was refluxed for $6 \mathrm{~h}$. After cooling, the solution was poured into water $(50 \mathrm{~mL})$ 
and the crude product was extracted with chloroform $(3 \times$ $50 \mathrm{~mL}$ ). The organic layer was dried over $\mathrm{Na}_{2} \mathrm{SO}_{4}$ and the solvent was removed under reduced pressure. The residue was chromatographed on silica gel with methanol/dichloromethane $(1: 10)$ to give compound SD-2 $(0.29 \mathrm{~g}, 76.3 \%)$ in a red solid, mp $237-$ $239^{\circ} \mathrm{C} .{ }^{1} \mathrm{H}$ NMR $\left(400 \mathrm{MHz}, \mathrm{DMSO}-d_{6}\right): \delta=8.04(\mathrm{~s}, 1 \mathrm{H}), 8.01$ (s, 2H), $7.93(\mathrm{~s}, 1 \mathrm{H}), 7.69$ (d, $J=4.0 \mathrm{~Hz}, 2 \mathrm{H}), 7.65$ (d, $J=8.8 \mathrm{~Hz}$, $2 \mathrm{H}), 7.53(\mathrm{~d}, J=4.0 \mathrm{~Hz}, 1 \mathrm{H}), 7.49(\mathrm{~d}, J=8.8 \mathrm{~Hz}, 4 \mathrm{H}), 7.45(\mathrm{~d}$, $J=8.8 \mathrm{~Hz}, 2 \mathrm{H}), 7.42(\mathrm{~s}, 2 \mathrm{H}), 7.07-7.00(\mathrm{~m}, 7 \mathrm{H}), 6.70(\mathrm{~d}, J=7.6$ $\mathrm{Hz}, 2 \mathrm{H}), 6.53$ (s, 2H), 3.47 (q, 8H), 1.25 (t, 12H). MS (MALDITOF): $m / z 905.1\left[\mathrm{M}^{+}\right]$(calcd for $\mathrm{C}_{56} \mathrm{H}_{48} \mathrm{~N}_{4} \mathrm{O}_{6} \mathrm{~S}$ 905.0). Anal. calcd (\%) for $\mathrm{C}_{56} \mathrm{H}_{48} \mathrm{~N}_{4} \mathrm{O}_{6} \mathrm{~S}$ : C 74.31, H 5.35, N 6.19, S 3.54. Found: C 74.28, H 5.60, N 6.08, S 3.41\%.

\section{5-[4- $\{N, N$-Bis(4-iodophenyl) $\}$ amino]phenyl-2,2'-bithiophene (8)}

To a solution of compound $4(3.20 \mathrm{~g}, 5.13 \mathrm{mmol})$ and 2,2'bithiophene-5-boronic acid pinacol ester $(0.50 \mathrm{~g}, 1.71 \mathrm{mmol})$ in DMF $(20 \mathrm{~mL})$ were added $\mathrm{Pd}\left(\mathrm{PPh}_{3}\right)_{4}(79 \mathrm{mg}, 0.068 \mathrm{mmol})$ and $\mathrm{K}_{2} \mathrm{CO}_{3}(0.62 \mathrm{~g}, 5.15 \mathrm{mmol})$, and the mixture was stirred at $60^{\circ} \mathrm{C}$ for $2 \mathrm{~h}$. After cooling, the solution was poured into water $(50 \mathrm{~mL})$ and the crude product was extracted with dichloromethane $(3 \times$ $50 \mathrm{~mL}$ ). The organic layer was dried over $\mathrm{Na}_{2} \mathrm{SO}_{4}$ and the solvent was removed under reduced pressure. The residue was chromatographed on silica gel with dichloromethane/n-hexane $(1: 3)$ to give compound $8(0.70 \mathrm{~g}, 61.9 \%)$ in a white solid, mp $133^{\circ} \mathrm{C} .{ }^{1} \mathrm{H}$ NMR (400 MHz, $\left.\mathrm{CDCl}_{3}\right): \delta=7.58(\mathrm{~d}, J=8.8 \mathrm{~Hz}, 4 \mathrm{H}), 7.49$ (d, $J=8.8 \mathrm{~Hz}, 2 \mathrm{H}), 7.24(\mathrm{~d}, J=4.0 \mathrm{~Hz}, 1 \mathrm{H}), 7.20(\mathrm{~d}, J=4.0 \mathrm{~Hz}$, $1 \mathrm{H}), 7.16(\mathrm{q}, J=4.0,4.0 \mathrm{~Hz}, 2 \mathrm{H}), 7.08(\mathrm{~d}, J=8.8 \mathrm{~Hz}, 2 \mathrm{H}), 7.02$ $(\mathrm{m}, 1 \mathrm{H}), 6.89(\mathrm{~d}, J=8.8 \mathrm{~Hz}, 4 \mathrm{H})$. Anal. calcd (\%) for $\mathrm{C}_{25} \mathrm{H}_{17} \mathrm{NS}_{2} \mathrm{I}_{2}: \mathrm{C} 47.22, \mathrm{H} 2.59, \mathrm{~N} 2.12, \mathrm{~S} 9.70$. Found: C 47.10, H 2.66, N 2.03, S 9.55\%.

\section{$5^{\prime}$-[4-\{N,N-Bis(4-iodophenyl)\}amino|phenyl-2,2'-bithiophene-5- carboxaldehyde (9)}

To a solution of compound $8(0.70 \mathrm{~g}, 1.06 \mathrm{mmol})$ in 1,2-dichloroethane $(20 \mathrm{~mL})$ were added DMF $(0.25 \mathrm{~mL}, 3.18 \mathrm{mmol})$ and $\mathrm{POCl}_{3}(0.30 \mathrm{~mL}, 3.18 \mathrm{mmol})$, and the mixture was refluxed for $16 \mathrm{~h}$. After cooling, the solution was poured into saturated aqueous sodium acetate solution $(50 \mathrm{~mL})$ and the crude product was extracted with dichloromethane $(3 \times 50 \mathrm{~mL})$. The organic layer was dried over $\mathrm{Na}_{2} \mathrm{SO}_{4}$ and the solvent was removed under reduced pressure. The residue was chromatographed on silica gel with dichloromethane to give compound $9(0.50 \mathrm{~g}, 68.5 \%)$ in a yellowish solid, mp $191{ }^{\circ} \mathrm{C} .{ }^{1} \mathrm{H}$ NMR $\left(400 \mathrm{MHz}, \mathrm{CDCl}_{3}\right): \delta=$ $9.87(\mathrm{~s}, 1 \mathrm{H}), 7.68(\mathrm{~d}, J=4.0 \mathrm{~Hz}, 1 \mathrm{H}), 7.58(\mathrm{~d}, J=8.8 \mathrm{~Hz}, 4 \mathrm{H})$, $7.50(\mathrm{~d}, J=8.8 \mathrm{~Hz}, 2 \mathrm{H}), 7.35(\mathrm{~d}, J=4.0 \mathrm{~Hz}, 1 \mathrm{H}), 7.28(\mathrm{~d}, J=4.0$ $\mathrm{Hz}, 1 \mathrm{H}), 7.22(\mathrm{~d}, J=4.0 \mathrm{~Hz}, 1 \mathrm{H}), 7.08(\mathrm{~d}, J=8.8 \mathrm{~Hz}, 2 \mathrm{H}), 6.88$ (d, $J=8.8 \mathrm{~Hz}, 4 \mathrm{H}$ ). Anal. calcd (\%) for $\mathrm{C}_{27} \mathrm{H}_{17} \mathrm{NOS}_{2} \mathrm{I}_{2}: \mathrm{C} 47.04$, H 2.49, N 2.03, S 9.30. Found: C 46.81, H 2.66, N 1.95, S 9.19\%.

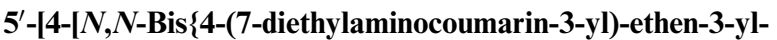 phenyl\}amino||phenyl-2,2'-bithiophene-5-carboxaldehyde (10)}

To a solution of compound $9(0.24 \mathrm{~g}, 0.35 \mathrm{mmol})$ and compound $2(0.20 \mathrm{~g}, 0.82 \mathrm{mmol})$ in DMF $(10 \mathrm{~mL})$ were added $\mathrm{Pd}(\mathrm{OAc})_{2}$ (4 mg, $0.017 \mathrm{mmol}), \mathrm{Bu}_{4} \mathrm{NBr}(0.22 \mathrm{~g}, 0.70 \mathrm{mmol})$ and $\mathrm{K}_{2} \mathrm{CO}_{3}$ $(0.17 \mathrm{~g}, 1.40 \mathrm{mmol})$, and the mixture was stirred at $95^{\circ} \mathrm{C}$ for $16 \mathrm{~h}$. After cooling, the solution was poured into water $(50 \mathrm{~mL})$ and the crude product was extracted with dichloromethane $(3 \times 50 \mathrm{~mL})$. The organic layer was dried over $\mathrm{Na}_{2} \mathrm{SO}_{4}$ and the solvent was removed under reduced pressure. The residue was chromatographed on silica gel with acetone/dichloromethane $(1: 50)$ to give compound $7(0.16 \mathrm{~g}, 53.3 \%)$ in a red solid, $\mathrm{mp}$ $243{ }^{\circ} \mathrm{C} .{ }^{1} \mathrm{H}$ NMR $\left(400 \mathrm{MHz}, \mathrm{CDCl}_{3}\right): \delta=9.81(\mathrm{~s}, 1 \mathrm{H}), 7.70(\mathrm{~s}$, $2 \mathrm{H}), 7.53-7.40(\mathrm{~m}, 7 \mathrm{H}), 7.35-7.25(\mathrm{~m}, 7 \mathrm{H}), 7.20(\mathrm{~d}, J=4.0 \mathrm{~Hz}$, $1 \mathrm{H}), 7.15(\mathrm{~m}, 5 \mathrm{H}), 7.05(\mathrm{~d}, J=8.8 \mathrm{~Hz}, 2 \mathrm{H}), 6.62(\mathrm{dd}, J=2.4$, $2.4 \mathrm{~Hz}, 2 \mathrm{H}), 6.55(\mathrm{~d}, J=2.4 \mathrm{~Hz}, 2 \mathrm{H}), 3.42(\mathrm{q}, 8 \mathrm{H}), 1.22(\mathrm{t}, 12 \mathrm{H})$. Anal. calcd (\%) for $\mathrm{C}_{57} \mathrm{H}_{49} \mathrm{~N}_{3} \mathrm{O}_{5} \mathrm{~S}_{2}$ : C 74.40, H 5.37, N 4.57, S 6.97. Found: C 74.18, H 4.83, N 4.39, S 6.73\%.

\section{3-[5'-[4-[N,N-Bis\{4-(7-diethylaminocoumarin-3-yl)-ethen-3-yl- phenyl\}amino||phenyl-2,2'-bithien-2-yl]-2-cyanoacrylic acid (SD-5)}

To a solution of compound $\mathbf{1 0}(0.16 \mathrm{~g}, 0.18 \mathrm{mmol})$ in chloroform $(20 \mathrm{~mL})$ were added cyanoacetic acid $(0.16 \mathrm{~g}, 1.83 \mathrm{mmol})$ and piperidine $(0.05 \mathrm{~mL}, 0.54 \mathrm{mmol})$, and the mixture was refluxed for $6 \mathrm{~h}$. After cooling, the solution was poured into water $(50 \mathrm{~mL})$ and the crude product was extracted with chloroform $(3 \times 50 \mathrm{~mL})$. The organic layer was dried over $\mathrm{Na}_{2} \mathrm{SO}_{4}$ and the solvent was removed under reduced pressure. The residue was chromatographed on silica gel with methanol/dichloromethane $(1: 5)$ to give compound SD-5 $(0.14 \mathrm{~g}, 82.4 \%)$ in a red solid, mp $259^{\circ} \mathrm{C} .{ }^{1} \mathrm{H}$ NMR $\left(400 \mathrm{MHz}\right.$, DMSO- $\left.d_{6}\right): \delta=8.06(\mathrm{~s}, 2 \mathrm{H}), 7.09$ (s, $2 \mathrm{H}), 7.92(\mathrm{~s}, 1 \mathrm{H}), 7.63-7.58(\mathrm{~m}, 4 \mathrm{H}), 7.50-7.38(\mathrm{~m}, 10 \mathrm{H}), 7.05-$ $6.95(\mathrm{~m}, 7 \mathrm{H}), 6.68(\mathrm{~d}, J=7.6 \mathrm{~Hz}, 2 \mathrm{H}), 6.50(\mathrm{~s}, 2 \mathrm{H}), 3.47(\mathrm{q}, 8 \mathrm{H})$,

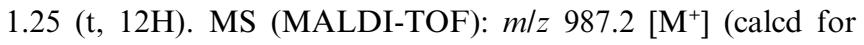
$\mathrm{C}_{60} \mathrm{H}_{50} \mathrm{~N}_{4} \mathrm{O}_{6} \mathrm{~S}_{2}$ 987.2). Anal. calcd (\%) for $\mathrm{C}_{60} \mathrm{H}_{50} \mathrm{~N}_{4} \mathrm{O}_{6} \mathrm{~S}_{2}$ : C 73.00, H 5.11, N 5.68, S 6.50. Found: C 72.84, H 5.81, N 5.37, S $6.39 \%$.

\section{Optical and voltammetric measurements}

Optical measurements were carried out in $1 \mathrm{~cm}$ cuvettes with Merck Uvasol grade solvents, absorption spectra recorded on a Perkin Elmer Lambda 19 spectrometer. Cyclic voltammetry experiments were performed with a computer-controlled EG\&G PAR 273 potentiostat in a three-electrode single-compartment cell with a platinum working electrode, a platinum wire counter electrode, and an $\mathrm{Ag} / \mathrm{AgCl}$ reference electrode. All potentials were internally referenced to the ferrocene/ferrocenium $\left(\mathrm{Fc}_{\mathrm{Fc}} / \mathrm{Fc}^{+}\right)$ couple.

\section{Device fabrication}

Screen-printed double layers of $\mathrm{TiO}_{2}$ particles were used as photoelectrodes in this study. An $8 \mu \mathrm{m}$ thick film of $20 \mathrm{~nm}$ sized $\mathrm{TiO}_{2}$ particles was first printed on the fluorine doped $\mathrm{SnO}_{2}$ (FTO) conducting glass electrode and coated with second layer (5 $\mu \mathrm{m}$ thick) comprised of $400 \mathrm{~nm}$ light-scattering anatase particles (CCI, Japan). After sintering the $\mathrm{TiO}_{2}$ layers at $500{ }^{\circ} \mathrm{C}$, the film was cooled to room temperature and immersed overnight in $0.02 \mathrm{M}$ aqueous $\mathrm{TiCl}_{4}$. The porosity was evaluated as $67 \%$ for the $20 \mathrm{~nm} \mathrm{TiO}_{2}$ transparent layer and $42 \%$ for the $400 \mathrm{~nm} \mathrm{TiO}_{2}$ scatting layer, determined from BET measurements. Solar cell fabrication was performed according to prior literature. ${ }^{6}$ Before using, the films were annealed in air at $500{ }^{\circ} \mathrm{C}$ for $30 \mathrm{~min}$ and cooling to $80^{\circ} \mathrm{C}$. The $\mathrm{TiO}_{2}$ electrodes were 
sensitized by dipping for $5 \mathrm{~h}$ in the dye solution $(150 \mu \mathrm{M})$ containing 10\% DMSO in chlorobenzene. Cells were sealed with a thermal platinized FTO/glass counter electrode using a $25 \mu \mathrm{m}$ thin hot-melt (Surlyn, Dupont). Cells were then filled with an electrolyte through a hole in the counter electrode. The hole was sealed with a Surlyn disc and a thin glass to avoid leakage of the electrolyte. The composition of Z960 electrolyte is $1.0 \mathrm{M} \mathrm{1,3-}$ dimethylimidazolium iodide, $0.03 \mathrm{M} \mathrm{I}_{2}, 0.05 \mathrm{M}$ lithium iodide, $0.1 \mathrm{M}$ guanidinium thiocyanate and $0.5 \mathrm{M}$ tert-butylpyridine in acetonitrile and valeronitrile solvent mixture $(85: 15$, v/v). For the solid-state devices, a compact $\mathrm{TiO}_{2}$ layer was first deposited onto the FTO substrate by spray pyrolysis, onto which $20 \mathrm{~nm}$ sized $\mathrm{TiO}_{2}$ particles were deposited to obtain a $2 \mu \mathrm{m}$ thick mesoporous film. The hole conductor material solution contains 0.17 M Spiro-MeOTAD, $0.11 \mathrm{mM}$ tert-butylpyridine, and $0.21 \mathrm{mM}$ $\mathrm{LiN}\left(\mathrm{CF}_{3} \mathrm{SO}_{2}\right)_{2}$ in chlorobenzene. The solution was deposited onto the dye-coated $\mathrm{TiO}_{2}$ film, leaving it to penetrate into the pores of the $\mathrm{TiO}_{2}$ layer for $1 \mathrm{~min}$ prior to spin coating. Finally, a $100 \mathrm{~nm}$ thick gold contact was deposited onto the organic semiconductor to close the cell.

\section{Photovoltaic characterization}

A $450 \mathrm{~W}$ xenon light source (Oriel, USA) was used to characterize the solar cells. The spectral output of the lamp was matched in the region of $350-750 \mathrm{~nm}$ with the aid of a Schott K113 Tempax sunlight filter (Präzisions Glas \& Optik GmbH, Germany) so as to reduce the mismatch between the simulated and true solar spectra to less than $4 \%$. The current-voltage characteristics of the cell under these conditions were obtained by applying external potential bias to the cell and measuring the generated photocurrent with a Keithley model 2400 digital source meter (Keithley, USA). A similar data acquisition system was used to control the incident photon-to-current conversion efficiency (IPCE) measurement. Under computer control, light from a $300 \mathrm{~W}$ xenon lamp (ILC Technology, USA) was focused through a Gemini-180 double monochromator (Jobin Yvon Ltd., UK) onto the photovoltaic cell under test. The devices were masked to attain an illuminated active area of $0.158 \mathrm{~cm}^{2}$.

\section{Photoinduced adsorption (PIA) measurements}

The PIA spectra of the various cells were recorded over a wavelength range of approximately $500-1500 \mathrm{~nm}$ following a (on/off) photo-modulation using a $9 \mathrm{~Hz}$ square wave emanating from a blue LED (470 $\mathrm{nm})$. White probe light from a halogen lamp $(20 \mathrm{~W})$ was used as an illumination source.

\section{Laser study}

Nanosecond laser flash photolysis technique was applied to dyesensitized, $8 \mu \mathrm{m}$ thick, transparent $\mathrm{TiO}_{2}$ mesoporous films deposited on normal flint glass. The samples were excited by pulses produced at a repetition rate of $30 \mathrm{~Hz}$ by a broad-band optical parametric oscillator (GWU OPO-355) pumped by a Powerlite 7030 frequency-tripled Q-switched Nd:YAG laser (Continuum, Santa Clara, California, USA). The output excitation wavelength was tuned at $\lambda=505 \mathrm{~nm}$ with a pulse width of $7 \mathrm{~ns}$ (fwhm). The laser beam was expanded by a planoconcave lens to irradiate a large cross-section of the sample, whose surface was kept at a $30^{\circ}$ angle to the excitation beam. The laser fluence on the sample was kept at a low level $\left(30 \mu \mathrm{J} \mathrm{cm}^{-2}\right.$ per pulse) to ensure that, on average, less than one electron is injected per nanocrystalline $\mathrm{TiO}_{2}$ particle upon pulsed irradiation. The probe light, produced by a continuous wave xenon arc lamp, was first passed through a monochromator tuned at $650 \mathrm{~nm}$, various optical elements, the sample, and then through a second monochromator, before being detected by a fast photomultiplier tube (Hamamatsu, R9110). Data waves were recorded on a DSA 602A digital signal analyser (Tektronix, Beaverton, Oregon, USA). Satisfactory signal-to-noise ratios were typically obtained by averaging over 1500 laser shots.

\section{Results and discussion}

\section{Synthesis}

The synthesis of the organic sensitizers SD-1, SD-2 and SD-5 was performed by following the steps as depicted in Scheme 1. Every step of the reaction sequence proceeded smoothly and efficiently to give a good or moderate yield of the product (see Experimental section for the synthetic details). The aldehyde $\mathbf{3}$ was synthesized by Heck reaction ${ }^{25}$ of two iodo groups in $\mathbf{1}^{\mathbf{2 2}}$ with the vinyl group in $\mathbf{2}^{\mathbf{2 3}}$ using $\mathrm{Pd}(\mathrm{OAc})_{2}$ as catalyst. Compound $\mathbf{3}$ was then reacted with cyanoacetic acid in the presence of piperidine to produce the sensitizer SD-1 in $74.4 \%$ yield. Sensitizer SD-2 was synthesized
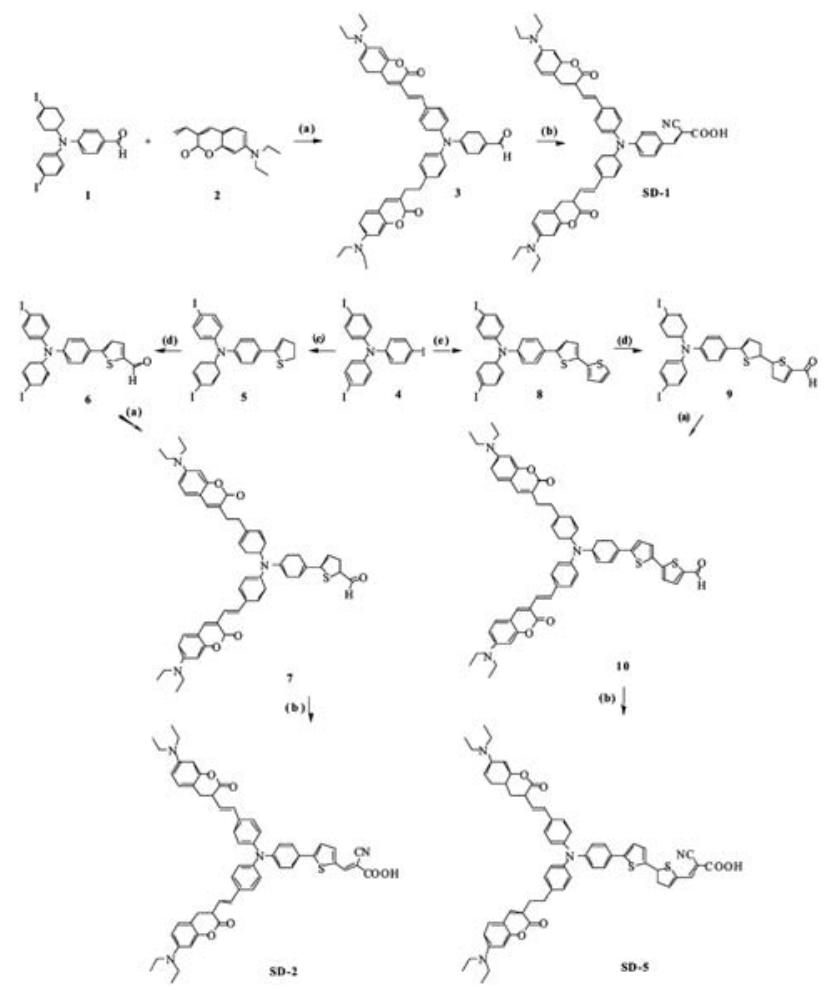

Scheme 1 Synthesis of SD-1, SD-2 and SD-5: (a) compound 2, $\mathrm{Pd}(\mathrm{OAc})_{2}, \mathrm{Bu}_{4} \mathrm{NBr}, \mathrm{K}_{2} \mathrm{CO}_{3}$, DMF, $95{ }^{\circ} \mathrm{C}, 16 \mathrm{~h}, 60 \%$ for $3,100 \%$ for 7 , and $53.3 \%$ for 10 ; (b) cyanoacetic acid, piperidine, chloroform, reflux, $6 \mathrm{~h}, 74.4 \%$ for SD-1, for $76.3 \%$ for SD-2, and $82.4 \%$ for SD-5; (c) 2thienylboronic acid, $\mathrm{Pd}(\mathrm{OAc})_{2}, \mathrm{PPh}_{3}, \mathrm{~K}_{2} \mathrm{CO}_{3}, \mathrm{DMF}, 80^{\circ} \mathrm{C}, 2 \mathrm{~h}, 26.5 \%$ for 5; (d) $\mathrm{POCl}_{3}$, DMF, 1,2-dichloroethane, reflux, $16 \mathrm{~h}, 68.2 \%$ for $\mathbf{6}$, $68.5 \%$ for 9; and (e) 2,2'-bithiophene-5-boronic acid pinacol ester, $\mathrm{Pd}\left(\mathrm{PPh}_{3}\right)_{4}, \mathrm{~K}_{2} \mathrm{CO}_{3}$, DMF, $60{ }^{\circ} \mathrm{C}, 2 \mathrm{~h}, 61.9 \%$ for 8 . 
starting from tris(4-iodophenyl)amine (4), ${ }^{24}$ which was reacted with commercially available 2 -thienylboronic acid under Suzuki reaction condition to give $\mathbf{5}$ in $26.5 \%$ yield. Subsequent formylation afforded 6 in $68.2 \%$. A 2-fold Heck-type cross-coupling reaction of diiodinated aldehyde $\mathbf{6}$ with vinyl group of compound 2 produced coumarin-substituted aldehyde 7 quantitatively. Finally, Knoevenagel condensation of aldehyde 7 and cyanoacetic acid gave the sensitizer SD-2 in 76.3\% yield. Starting from compound 4, the sensitizer SD-5 was also prepared via corresponding precursor compounds 8-10 using analogous procedures for SD-2.

The sensitizers SD-1, SD-2 and SD-5 and their precursor compounds 3-10 are highly soluble in aromatic solvents (i.e., toluene, $o$-dichlorobenzene and benzonitrile) and other common organic solvents (i.e., acetone, ethanol, $\mathrm{CH}_{2} \mathrm{Cl}_{2}, \mathrm{CHCl}_{3}$, DMF, DMSO and THF). The structure and purity of the new compounds were confirmed by ${ }^{1} \mathrm{H}$ NMR and elemental analysis. ${ }^{1} \mathrm{H}$ NMR spectra of these compounds are consistent with the proposed structures, showing the expected features with the correct integration ratios. The MALDI-TOF mass spectra provide a direct evidence for the structures of SD-1, SD-2 and SD-5 showing a singly charged molecular ion peak at $\mathrm{m} / \mathrm{z}=$ 823.2, 905.1 and 987.2, respectively, that matches the calculated value for the molecular weight of each compound. Further confirmation of the compounds SD-1, SD-2 and SD-5 was obtained from the steady-state UV/vis measurements as shown in the forthcoming sections.

The absorption and emission spectra of dyes in dichloromethane solution are displayed in Fig. 2 and the corresponding data are presented in Table 1. SD-1 shows an absorption maximum in the visible region at $454 \mathrm{~nm}$, with a molar extinction coefficient of $5.9 \times 10^{4} \mathrm{M}^{-1} \mathrm{~cm}^{-1}$, arising from $\pi-\pi^{*}$ charge transfer (CT) transitions. Upon inserting two thiophene units between donor and acceptor units, the absorption spectra of SD5 are red shifted by $10 \mathrm{~nm}$ compared to SD-1. It is interesting to note that the absorption spectra peak maxima of these three dyes have close values but there is a big difference in the emission spectra peak maxima position. Due to the insertion of two thiophene units in the spacer, there is a large Stokes shift observed for SD-5 compared to SD-1. This suggests that adding more thiophene units makes the structure more flexible giving rise to broadening of the excited state surface.

The observed spectroscopic behavior in solution was corroborated by DFT calculations using B3LYP/6-31G* method from

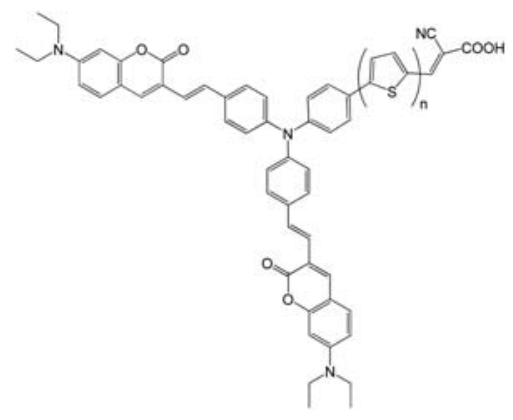

Fig. 1 Molecular structures of SD-1, SD-2 and SD-5 where $n=0,1$ and 2 , respectively.
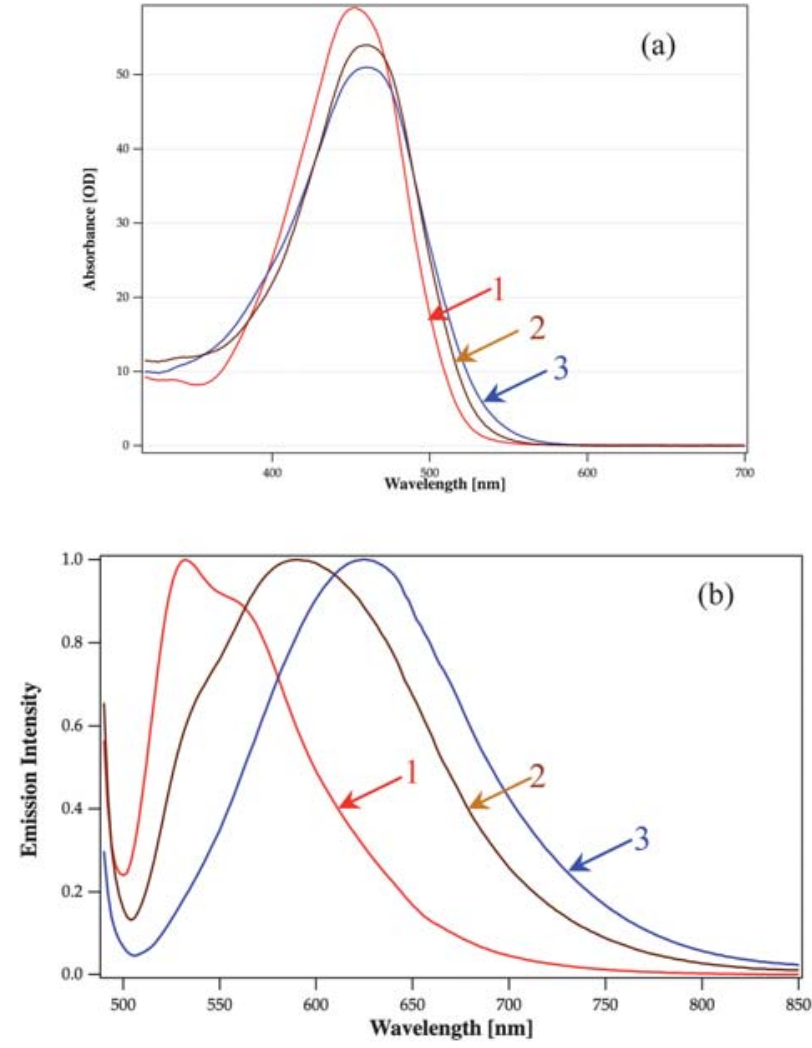

Fig. 2 Absorption spectra (a) and emission spectra (b) of SD-1 (red, curve 1), SD-2 (brown, curve 2) and SD-5 (blue, curve 3), measured in dichloromethane.

Spartan software, Wavefunction (Fig. 3). The electron density of the highest occupied molecular orbitals (HOMOs) of the three molecules is mainly located on the diphenylamine moieties, whereas electron density of the lowest unoccupied molecular orbital (LUMO) is primarily located at the cyanoacrylic acid acceptor and the neighbouring thiophene ring. Hence, the presence of strong electron density relocation between HOMO and LUMO is present and supports an intramolecular charge transfer transition (ICT) in the UV/vis spectra. ${ }^{26}$ Furthermore, the calculated electron distribution shows vectorization for injection of photoexcited electrons from the donor group to the $\mathrm{TiO}_{2}$ film via the anchoring group.

The energetic alignment of HOMO and LUMO energy levels is crucial for an efficient operation of the sensitizer in a DSC. To ensure efficient electron injection from the excited dye molecules

Table 1 Optical and electrochemical data of SD-1, SD-2 and SD-5 dyes measured from dichloromethane solvent

\begin{tabular}{llll}
\hline Dye & $\lambda / \mathrm{nm}\left(\varepsilon / \mathrm{L} \mathrm{mol}^{-1} \mathrm{~cm}^{-1}\right)$ & Emission $\lambda_{\max }$ & $E_{\text {ox }}^{0}{ }^{a, b} / \mathrm{V}$ \\
\hline SD-1 & $454\left(5.9 \times 10^{4}\right)$ & 525 & 0.322 \\
SD-2 & $460\left(5.4 \times 10^{4}\right)$ & 590 & 0.283 \\
SD-5 & $465\left(5.1 \times 10^{4}\right)$ & 640 & 0.192
\end{tabular}

${ }^{a}$ Measured in DCM/TBAHFP $(0.1 \mathrm{M}), c \approx 1 \times 10^{-3} \mathrm{~mol} \mathrm{~L}^{-1}, 295 \mathrm{~K}$, scan rate $=100 \mathrm{mV} \mathrm{s}^{-1}$. The potential was calibrated with a $\mathrm{Fc} / \mathrm{Fc}^{+}$ redox couple. ${ }^{b}$ Values determined by cyclic voltammetry measurements. 


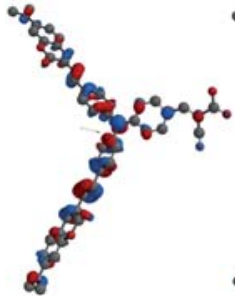

(a)

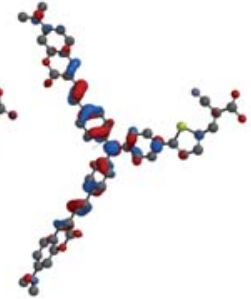

(b)

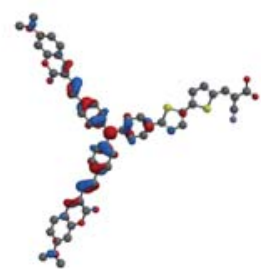

(c)

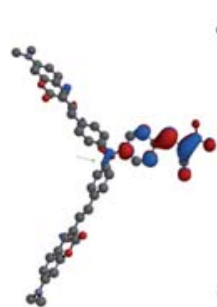

(d)

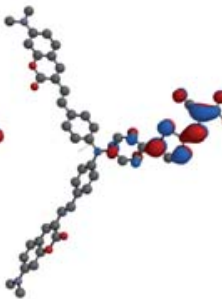

(e)

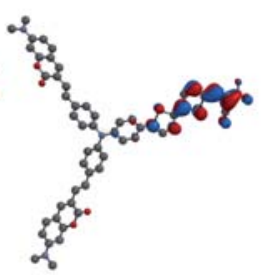

(f)
Fig. 3 DFT calculations of SD-1, SD-2 and SD-5 dyes HOMO (a, b, and c) and LUMO (d, e, and f), respectively.

into the conduction band of the $\mathrm{TiO}_{2}$ film, the LUMO level must be higher in energy than the $\mathrm{TiO}_{2}$ conduction band edge. The HOMO level of the dye must be lower in energy than the redox potential of the iodide/triiodide redox couple for efficient regeneration of the dye cation subsequent to photoinduced electron injection into the $\mathrm{TiO}_{2}$ film. The electrochemical behaviour of the dyes was investigated by cyclic voltammetry, and the data are listed in Table 1. All of the three dyes exhibit reversible waves for the oxidation, corresponding to the HOMO energy of the dye, at a potential greater than that of $\mathrm{I}^{-} / \mathrm{I}_{3}{ }^{-}$couple, which assures regeneration of the neutral dye from its oxidized state. The oxidation potential of SD-1 $(0.32 \mathrm{~V})>$ SD-2 $(0.28 \mathrm{~V})>$ SD-5 $(0.19 \mathrm{~V})$ indicating that the insertion of thiophene as a spacer between the donor and acceptor decreases the HOMO energy level of the dye due to the electron rich character of thiophene (Table 1).

The photovoltaic parameters, i.e. conversion efficiency $(\eta)$, short-circuit photocurrent density $\left(J_{\mathrm{sc}}\right)$, the open-circuit photovoltage $\left(V_{\mathrm{oc}}\right)$, and the fill factor $(\mathrm{FF})$ under full sunlight (AM $1.5 \mathrm{G}, 100 \mathrm{~mW} \mathrm{~cm}{ }^{-2}$ ) of devices with volatile electrolyte, ionic liquid, and a solid-state hole conductor are summarized in

Table 2 Photovoltaic parameters of devices with sensitizers SD-1, SD-2 and SD-5 in liquid, ionic liquid and solid-state based DSCs at full sunlight (AM 1.5G, $100 \mathrm{~mW} \mathrm{~cm}^{-2}$ )

\begin{tabular}{|c|c|c|c|c|}
\hline Device Dye & Electrolyte & \multicolumn{3}{|c|}{$V_{\mathrm{oc}} / \mathrm{mV} J_{\mathrm{sc}} / \mathrm{mA} \mathrm{cm}^{-2} \mathrm{FF} \quad \eta(\%)$} \\
\hline A & SD-1 Volatile electrolyte (Z960) & 800 & 9.0 & 0.765 .5 \\
\hline B & SD-2 & 695 & 12.2 & 0.746 .2 \\
\hline $\mathrm{C}$ & SD-5 & 678 & 13.2 & 0.676 .0 \\
\hline $\mathrm{D}$ & SD-1 Ionic liquid (Z952) & 740 & 8.0 & 0.774 .8 \\
\hline E & SD-2 & 693 & 10.0 & 0.755 .1 \\
\hline $\mathrm{F}$ & SD-5 & 651 & 10.3 & 0.755 .0 \\
\hline G & SD-1 Solid hole conductor & 800 & 6.4 & 0.432 .2 \\
\hline $\mathrm{H}$ & SD-2 & 835 & 7.7 & 0.493 .1 \\
\hline I & SD-5 & 790 & 6.9 & 0.472 .6 \\
\hline
\end{tabular}

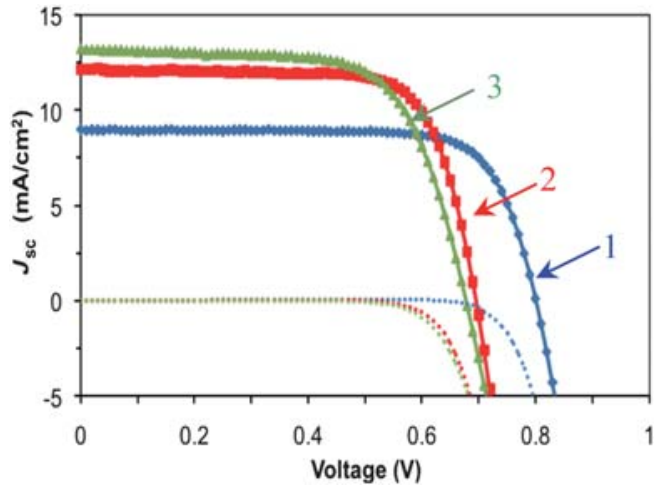

Fig. 4 Current density-voltage curve under full sunlight (AM1.5G, $100 \mathrm{~mW} \mathrm{~cm}^{-2}$ ) and in the dark of devices sensitized with SD-1 (blue, curve 1), SD-2 (red, curve 2) and SD-5 (green, curve 3) using a volatile electrolyte Z960.

Table 2. The photocurrent-voltage curves of the devices with volatile electrolyte are displayed in Fig. 4. The SD-2 sensitized cell (device B) provides a $J_{\mathrm{sc}}$ of $12.2 \mathrm{~mA} \mathrm{~cm} \mathrm{~cm}^{-2}$, a $V_{\mathrm{oc}}$ of $695 \mathrm{mV}$ and a FF of 0.74 , yielding an overall power conversion efficiency of $6.2 \%$ with a volatile electrolyte (Z960). The photovoltaic parameters of devices A (with SD-1) to C (with SD-5) are presented in Table 2. It is interesting to note that the $J_{\text {sc }}$ values are increasing for devices in the order of $\mathrm{C}>\mathrm{B}>\mathrm{A}$ with the increase in the number of thiophene unit as a spacer, where as the $V_{\text {oc }}$ values are in the decreasing order of $\mathrm{A}>\mathrm{B}>\mathrm{C}$. The open-circuit photovoltage difference between device $\mathrm{A}$ and device $\mathrm{C}$ is $122 \mathrm{mV}$ indicating that the insertion of thiophene as a spacer might be creating some charge recombination centre.

Fig. 5 shows the incident-photon-to-current conversion efficiency (IPCE) of devices A to $\mathrm{C}$ with a volatile electrolyte. The features of the spectral response of the photocurrent reflect closely to the absorption spectrum of the dyes. This exhibits a broad range of absorption from $400 \mathrm{~nm}$ to $675 \mathrm{~nm}$ with a peak maximum of $82 \%$ at $525 \mathrm{~nm}$. The $J_{\text {sc }}$ value derived from integrating the product of the IPCE spectrum with the AM 1.5G spectral solar photon flux agrees within less than $2 \%$ with the measured $J_{\mathrm{sc}}$ value showing that any spectral mismatch of the solar simulator with regard to the true standard AM 1.5G

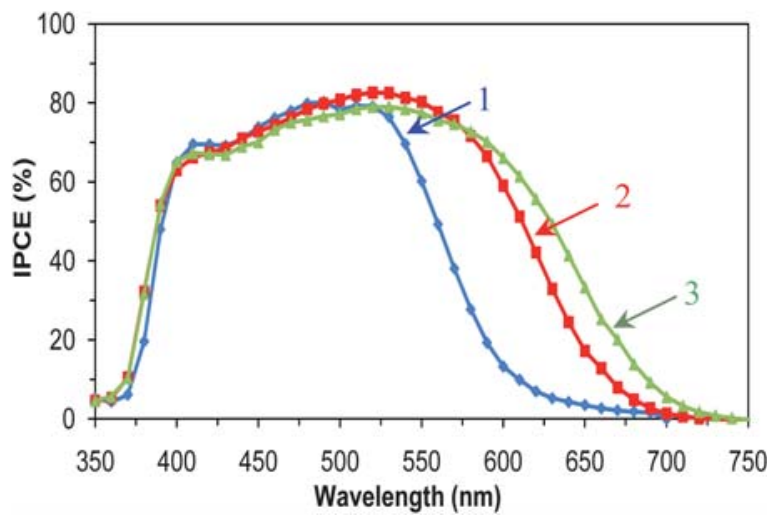

Fig. 5 Incident photo-to-current conversion efficiency of devices sensitized with SD-1 (blue, curve 1), SD-2 (red, curve 2) and SD-5 (green, curve 3) using a volatile electrolyte Z960. 
emission spectrum is negligible. Insertion of a thiophene in the spacer clearly shows the advantage in IPCE by absorbing more visible light in the red region of the spectrum. Hence we obtained highest current density with device $\mathrm{C}$ compared to devices $\mathrm{A}$ or $\mathrm{B}$, but the device $\mathrm{C}$ performance is lower than the device $\mathrm{B}$ due to the low FF value.

In addition to volatile liquid electrolytes, we fabricated devices using these new coumarin-substituted donor- $\pi$-acceptor organic dyes, in combination with a solvent free ionic liquid electrolyte and the results are tabulated in Table 2. As observed with volatile electrolytes the photovoltaic performance of device E with SD-2 dye is superior to SD-1 or SD-5 dye containing devices, reaching a maximum efficiency of $5.1 \%$ at full sunlight intensity. The photovoltaic parameters of solid-state devices prepared using the Spiro-MeOTAD as a hole-transporting material are summarized in Table 2. The device $(\mathrm{H})$ with $\mathbf{S D - 2}$ dye shows the best results with a $J_{\text {sc }}$ of $7.7 \mathrm{~mA} \mathrm{~cm}^{-2}$, a $V_{\text {oc }}$ of $835 \mathrm{mV}$, and a FF of 0.49 , resulting in a respectable photo-conversion efficiency of $3.1 \%$ under an illumination of the AM 1.5G full sunlight $(100 \mathrm{~mW}$ $\mathrm{cm}^{-2}$ ). The good performance of solid-state device $\mathrm{H}$ is in agreement with the results obtained with liquid electrolytes, but there is only a small decrease in $V_{\mathrm{oc}}$ of device $\mathrm{I}$ in comparison to device $G$ by introducing extra thiophene units in the spacer. These observed differences in $V_{\text {oc }}$ of liquid and solid state devices are due to the differences of solvent interactions with dye present in the liquid electrolytes compared to the solid hole transport material devices.

We obtained the spectrum of the dye cation by using the technique of photoinduced absorption spectroscopy (Fig. 6). For all of the dyes $670 \mathrm{~nm}$ was chosen as the dye cation absorption wavelength for monitoring the recombination and regeneration rates. A positive feature in the near infrared region is also distinguished, arising from the hole located on the triarylamine moiety of the molecule.

Laser transient absorbance measurements were carried out to observe the influence of thiophene spacer units on the reaction rates of both the charge recombination between the injected electron and the dye oxidized state (eqn (1)) and the reduction of the dye cation by iodide (eqn (2)). These two parallel reactions follow the ultrafast electron injection from the dye excited state into $\mathrm{TiO}_{2}$ and compete kinetically. ${ }^{27}$

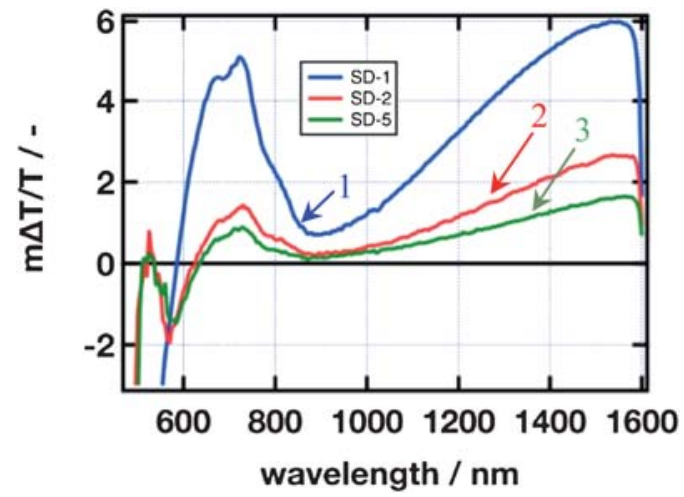

Fig. 6 Photoinduced absorbance spectra of the $\mathrm{TiO}_{2}$ photoanodes sensitized with three dyes of SD-1 (blue, curve 1), SD-2 (red, curve 2) and SD-5 (green, curve 3), $\lambda_{\mathrm{ex}}=470 \mathrm{~nm}$, repetition rate being $9 \mathrm{~Hz}$.

$$
\begin{gathered}
\mathrm{S}^{+}+\mathrm{e}_{\mathrm{cb}}^{-} \rightarrow \mathrm{S} \\
\mathrm{S}^{+}+2 \mathrm{I}^{-} \rightarrow \mathrm{S}+\mathrm{I}_{2}^{--}
\end{gathered}
$$

In a non-redox medium, such as pure acetonitrile, charges initially separated during the light-induced electron injection process have no other possibility than recombining. The transient absorbance monitored at $670 \mathrm{~nm}$ is characteristic of the dye oxidized state $\mathrm{S}^{+}$. The temporal analysis of the decay of this optical signal thus allows us to measure the half-reaction time of the recombination process $t_{1 / 2 \text {,rec }}$. Upon inserting one or two thiophene units, the recombination rate is observed to be significantly enhanced. The half-reaction time for recombination of SD-1 dye cation is $t_{1 / 2 \text {,rec. }}=2.6 \mathrm{~ms}$ (Fig. 7). Adding one thiophene unit in sensitizer SD-2 causes this half-reaction time to be reduced by almost two orders of magnitude to only $46 \mu \mathrm{s}$. Addition of a second thiophene unit in dye SD-5 does not influence the recombination rate any further $\left(t_{1 / 2 \text {,rec. }}=51 \mu \mathrm{s}\right)$. The addition of thiophene units between the cyanoacrylate anchoring group and the central triarylamine moiety was primarily expected to increase the distance between the oxide's surface and the part of the molecule on which the hole is located and thus to improve the charge separation efficiency. However, an opposite effect is clearly observed. As the nuclear reorganization energy associated with the charge recombination reaction should remain more or less the same for all three dyes, this observation suggests that the electron transfer distance is actually decreased upon addition of one or two thiophene units. Molecular modeling shows that a different conformation of the adsorbed dye can indeed prevail for SD-2 and SD-5, where one of the coumarin moieties can be in close contact with the $\mathrm{TiO}_{2}$ surface.

The temporal behavior of the transient absorbance of $\mathrm{S}^{+}$ species at the same wavelength was observed in the presence of the redox-active electrolyte (Z960). A much faster decay of the dye oxidized state was observed, showing that the reduction of the dye cation by iodide (eqn (2)) is competing efficiently with charge recombination. With SD-1 dye, the half-lifetime of the cation was $t_{1 / 2 \text {,reg }}=2.8 \mu \mathrm{s}$, indicating that the dye regeneration by the electrolyte is here $c a$. 3 orders of magnitude faster than the charge recombination reaction. The time constants for the reduction of SD-2 $\left(t_{1 / 2, \text { reg }}=3.4 \mu \mathrm{s}\right)$ and $\mathbf{S D - 5}\left(t_{1 / 2, \text { reg }}=10.7 \mu \mathrm{s}\right)$ cations are pretty similar to that of SD-1. Table 3 displays

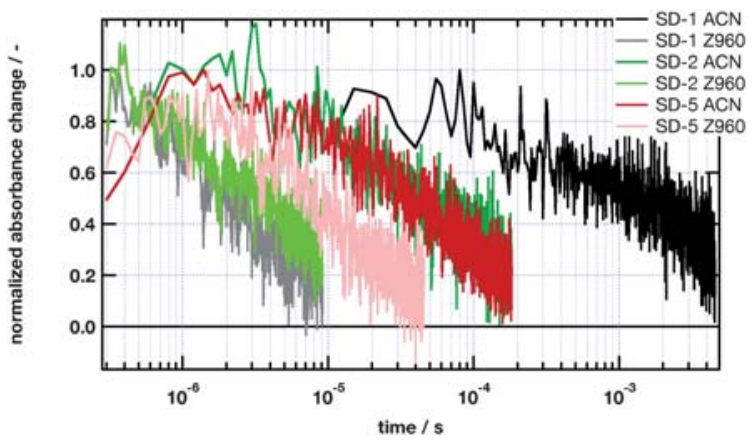

Fig. 7 Transient absorbance decay of the oxidized state of SD-1, SD-2 and SD-5 sensitizers adsorbed on nanocrystaline $\mathrm{TiO}_{2}$ films. The kinetics observed with acetonitrile, no iodide added $(\mathrm{ACN})$ and in the presence of redox electrolyte Z960 under similar conditions. 
Table 3 Transient absorbance half-reaction decay time of the oxidized state of SD-1, SD-2 and SD-5 sensitizers in the presence of acetonitrile $\left(t_{1 / 2, \text { rec. }}\right)$ or redox electrolyte $\mathrm{Z} 960\left(t_{1 / 2, \text { reg. }}\right)$

\begin{tabular}{llcc}
\hline Dye & Thiophene units & $t_{1 / 2, \text { rec. }} / \mu \mathrm{s}$ & $t_{1 / 2, \text { reg. }} / \mu \mathrm{s}$ \\
\hline SD-1 & 0 & 2574 & 2.8 \\
SD-2 & 1 & 46 & 3.4 \\
SD-5 & 2 & 51 & 10.7 \\
\hline
\end{tabular}

half-reaction times for charge recombination and dye cation interception measured for all three dye sensitizers in the absence and in the presence of the electrolyte, respectively. Assuming in a very coarse approximation first order kinetic laws for charge recombination and dye regeneration reactions as well as sufficient kinetic decoupling between both parallel processes, the dye cation interception efficiency can be approximated by $\eta=t_{1 / 2, \text { rec }}$. $\left(t_{1 / 2, \text { rec. }}+t_{1 / 2, \text { reg. }}\right)$, where $t_{1 / 2 \text {,reg. }}$ is the half-reaction time for dye cation interception by the electrolyte. The dye cation interception efficiency $=1,0.93$ and 0.83 is thus obtained for SD-1, SD-2 and SD-5, respectively.

In conclusion, we have synthesized three donor- $\pi$-acceptor metal free dyes containing coumarin substituted on the donor moiety and thiophenes as spacers between the donor and acceptor groups. These dyes were successfully employed as sensitizers in dye-sensitized solar cells. These new organic sensitizers performed efficiently with all types of electrolyte medium employed, i.e., volatile, solvent free ionic liquid electrolytes and an organic hole transport material spiro-MeOTAD containing devices. Increasing the number of thiophene units in the spacer shifts the spectral response to the red region of absorption spectra and enhances the photovoltaic performance of the devices by increasing the $J_{\mathrm{sc}}$ values with the absorption of more red photons. Laser studies indicate that there is a loss in efficiency of the interception of geminate recombination by iodide present in the redox electrolyte upon addition of thiophene units as spacers between the donor and acceptor units of the dye molecules.

\section{Acknowledgements}

The authors would like to thank P. Comte for the $\mathrm{TiO}_{2}$ film fabrication and the Swiss National Science Foundation for the financial support and Dr Carole Grätzel for fruitful discussions. L.A. is grateful to Prof. Filippo Pucciarelli and Dr Rita Giovannetti for granting a leave of absence and continued financial support. K.-Y. Kay also acknowledges the financial support from Brain Korea 21 Program in 2008.

\section{References}

1 B. O’Regan and M. Grätzel, Nature, 1991, 353, 737.

2 M. Grätzel, Acc. Chem. Res., 2009, 42, 1788.

3 M. K. Nazeeruddin, F. De Angelis, S. Fantacci, A. Selloni, G. Viscardi, P. Liska, S. Ito, B. Takeru and M. Grätzel, J. Am. Chem. Soc., 2005, 127, 16835.

4 Y. Chiba, A. Islam, Y. Watanabe, R. Komiya, N. Koide and L. Han, Jpn. J. Appl. Phys., Part 2, 2006, 45, L638.

5 F. Gao, Y. Wang, D. Shi, J. Zhang, M. Wang, X. Jing, R. HumphryBaker, P. Wang, S. M. Zakeeruddin and M. Grätzel, J. Am. Chem. Soc., 2008, 130, 10720.

6 C. Chen, M. Wang, J. Li, N. Pootrakulchote, C. Alibabaei, J. Decoppet, J. Tsai, C. Grätzel, C. Wu, S. Zakeeruddin and M. Grätzel, ACS Nano, 2009, 3, 3103.

7 K. Hara, T. Sato, R. Katoh, A. Furube, Y. Ohga, A. Shinpo, S. Suga, K. Sayama, H. Sugihara and H. Arakawa, J. Phys. Chem. B, 2003, $107,597$.

8 T. Horiuchi, H. Miura, K. Sumioka and S. Uchida, J. Am. Chem. Soc., 2004, 126, 12218.

9 W. Zeng, Y. Cao, Y. Bai, Y. Shi, M. Zhang, F. Wang, C. Pan and P. Wang, Chem. Mater., 2010, 22, 1915.

10 Y. Cao, Y. Bai, Q. Yu, Y. Cheng, S. Liu, D. Shi, F. Gao and P. Wang, J. Phys. Chem. C, 2008, 112, 6290-6297.

11 D. Hagberg, T. Edvinsson, T. Marinado, G. Boschloo, A. Hagfeldt and L. Sun, Chem. Commun., 2006, 2245.

12 N. Koumura, Z. Wang, S. Mori, M. Miyashita, E. Suzuki and K. Hara, J. Am. Chem. Soc., 2006, 128, 14256.

13 S. Ito, S. M. Zakeeruddin, R. Humphry-Baker, P. Liska, R. Charvet, P. Comte, M. K. Nazeeruddin, P. Péchy, M. Takata, H. Miura, S. Uchida and M. Grätzel, Adv. Mater., 2006, 18, 1202.

14 S. Hwang, J. H. Lee, C. Park, H. Lee, C. Kim, C. Park, M.-H. Lee, W. Lee, J. Park, K. Kim, N.-G. Park and C. Kim, Chem. Commun., 2007, 4887.

15 H. Choi, C. Baik, S. O. Kang, J. Ko, M.-S. Kang, Md. K. Nazeeruddin and M. Grätzel, Angew. Chem., Int. Ed., 2008, 47, 327.

16 Z. Wang, N. Koumura, Y. Cui, M. Takahashi, H. Sekiguchi, A. Mori, T. Kubo, A. Furube and K. Hara, Chem. Mater., 2008, 20, 3993.

17 N. Koumura, Z. Wang, M. Miyashita, H. Sekiguchi, Y. Cui, A. Mori, S. Mori and K. Hara, J. Mater. Chem., 2009, 19, 4829.

18 H. Choi, I. Raabe, D. Kim, F. Teocoli, C. Kim, K. Song, J. Yum, J. Ko, Md. K. Nazeeruddin and M. Grätzel, Chem.-Eur. J., 2010, 16, 1193.

19 D. Liu, R. Fessenden, G. Hug and P. Kamat, J. Phys. Chem. B, 1997, 101, 2583.

20 B. Burfeindt, T. Hannappel, W. Storck and F. Willig, J. Phys. Chem., 1996, 100, 16463.

21 K. Sayama, S. Tsukagoshi, K. Hara, Y. Ohga, A. Shinpou, Y. Abe, S. Suga and H. Arakawa, J. Phys. Chem. B, 2002, 106, 1363.

22 G. Koeckelberghs, M. Vangheluwe, I. Picard, L. Groof, T. Verbiest, A. Persoons and C. Samyn, Macromolecules, 2004, 37, 8530.

23 K. Hara, Y. Tachibana, Y. Ohga, A. Shinpo, S. Suga, K. Sayama, H. Sugihara and H. Arakawa, Sol. Energy Mater. Sol. Cells, 2003, $77,89$.

24 M. Sonntag, K. Kreger, D. Hanft, P. Strohriegl, S. Setayesh and D. Leeuw, Chem. Mater., 2005, 17, 3031.

25 R. F. Heck, Palladium Reagents in Organic Synthesis, Academic, London, 1985.

26 A. Mishra, M. Fischer and P. Bäuerle, Angew. Chem., Int. Ed., 2009, 48, 2474

27 V. K. Thorsmølle, B. Wenger, J. Teuscher, C. Bauer and J.-E. Moser, Chimia, 2007, 61, 631. 